\title{
Process Modelling and Optimization of Green Lube Oil Synthesis
}

\author{
Rasheed U. Owolabi*, Mohammed A. Usman, \\ Oribayo Oluwasola and Ikuejawa T. Samuel \\ University of Lagos \\ Chemical and Petroleum Engineering Department \\ Lagos State, Nigeria
}

Received 30.08.2020, received in revised form 03.10.2020, accepted 09.12.2020

\begin{abstract}
Modeling and optimization of trans-esterification of palm kernel oil (PKO) to trimethylolpropone ester (TMP ester- a bio-lubricant) via palm kernel oil methyl ester (PKOME-a biodiesel) synthesis were investigated. The central composite design (CCD) component of the response surface methodology (RSM) was adopted for the optimization of the process parameters, where temperature and weight ratio of PKOME to TMP were held constant at $130{ }^{\circ} \mathrm{C}$ and $3.9: 1$ respectively, to generate 20 experimental runs. Bio-lubricant yield was calculated for each experimental run. A quadratic-like model was generated that related the yield to the process parameters (Reaction time, Stirring Speed, and Catalyst concentration). The predicted and actual R2 value were 0.9856 and 0.9959 respectively, which indicate an excellent agreement between experimental and predicted biolubricant yield. The predicted maximum bio-lubricant yield was $98.11 \%$ at reaction time of 99.9084 mins, stirring speed of $863.794 \mathrm{rpm}$, and catalyst concentration $0.84522 \mathrm{wt}$ \% . The experimental value obtained under same conditions was $96.996 \%$. Physico-chemical analysis of the bio-lubricant synthesized at optimum conditions were found to be within the range of the ASTM standard for biolubricants.
\end{abstract}

Keywords: modelling, optimization, trans-esterification, bio-lubricant.

Citation: Owolabi R.U., Usman M.A., Oluwasola O., Ikuejawa T.S. Process modelling and optimization of green lube oil synthesis, J. Sib. Fed. Univ. Eng. \& Technol., 2020, 13(8), 1002-1017. DOI: 10.17516/1999-494X-0281

(C) Siberian Federal University. All rights reserved

This work is licensed under a Creative Commons Attribution-Non Commercial 4.0 International License (CC BY-NC 4.0).

* Corresponding author E-mail address: uthmanrash642@yahoo.com 


\title{
Моделирование процесса
}

\section{и оптимизация синтеза зеленого смазочного масла}

\author{
Р.Г. Оволаби, М.А. Усаман, \\ О. Олувасола, Т.С. Икуджава \\ Государственный университет Лагоса \\ Кафедра химического и нефтяного машиностроения \\ Нигерия, Лагос
}

\begin{abstract}
Аннотация. Были исследованы моделирование и оптимизация трансэтерификации косточкового пальмового масла (РКО) в сложный эфир триметилолпропана (сложный эфир ТМР - биолубрикант) посредством синтеза метилового эфира косточкового масла (РКОМЕ-а биодизель). Компонент центрального композитного дизайна (CCD) методологии поверхности отклика (RSM) был принят для оптимизации параметров процесса, где температура и массовое отношение РКОМЕ к ТМР поддерживались постоянными на уровне $130{ }^{\circ} \mathrm{C}$ и 3,9:1 соответственно, чтобы получить 20 экспериментальных прогонов. Ресурс биосмазки был рассчитан для каждого экспериментального цикла. Была создана квадратичная модель, которая связала выход с параметрами процесса (время реакции, скорость перемешивания и концентрация катализатора). Прогнозируемое и фактическое значения R2 составили 0,9856 и 0,9959 соответственно, что указывает на превосходное соответствие экспериментального и прогнозируемого выходов биосмазки. Прогнозируемый максимальный выход биосмазки был равен 98,11 \% при времени реакции 99,9084 мин, скорости перемешивания 863,794 об/мин и концентрации катализатора 0,84522 мас. \%. Экспериментальное значение, полученное при тех же условиях, составило 96,996 \%. Было обнаружено, что физико-химический анализ биосмазок, синтезированных в оптимальных условиях, находится в пределах диапазона стандарта ASTM для биосмазок.
\end{abstract}

Ключевые слова: моделирование, оптимизация, трансэтерификация, биосмазка.

Цитирование: Оволаби, Р.Г. Моделирование процесса и оптимизация синтеза зеленого смазочного масла / Р.Г. Оволаби, M.А. Усаман, О. Олувасола, Т.С. Икуджава // Журн. Сиб. федер. ун-та. Техника и технологии, 2020. 13(8). С. $1002-1017$. DOI: $10.17516 / 1999-494 X-0281$

\section{Introduction}

There is a global campaign for the replacement of synthetic products with bio-based or green products. This is as a result of the changing climate by virtue of the release of anthropogenic gases into the atmosphere. These gases find their ways into the atmosphere during the course of synthetic products production or through the environmental implications of the corresponding waste generated. Studies have also shown that about $93 \%$ of the biomass which are likely primary feedstocks for bio industrial processes are untapped and allowed to rot. On account of these, there is a strong need to harness the natural feedstocks such as bio-sourced oil for green lube production. More importantly, fossil fuels have been strongly associated with the release of greenhouse gases, majorly $\mathrm{CO}_{2}$. The drawback of the release are climate change, emergence of drought, spread of diseases and variation in population sizes of both plant and animal species [38], depletion of the world's crude oil reserve, hike in petroleum products prices, and issues related to conservation. The drawbacks have brought about renewed interest in the use of bio-based materials [70]. The non-biodegradability and nonrenewability of mineral lubricants and their associated contaminating effects in soil, water, and air, 
pose danger to public health and the environment where man, animals and plant operate. Emphasis by policy makers and science and engineering communities on the acceptance and adoption of renewable, biodegradable, and eco-friendly industrial fluids, such as diesel, lubricants which is considered herein and other fuels have raised the need to search for alternative renewable sources for them $[60,11,16,56,72,12]$.

Lubricant is a substance mostly fluid or semi-fluid like introduced between two moving surfaces to lower the friction between them, increase efficiency and lower wearing rate [34, 12]. Lubrication is the technique usually adopted to reduce wearing and tearing rate of one or both surfaces in contact by applying lubricant between the surfaces which is expected to carry load between the contacting surfaces $[26,52]$. In addition, lubricant serves as heat transfer medium, liquid sealing, contaminant suspension, and corrosion protection between closely moving surfaces. Previous researches have confirmed that the mono-unsaturated fatty acids in plants oils, specifically oleic, and palmitic, are ideal candidates for both lubricants and hydraulic oils [58]. Oleic acid for instance has been proved by earlier researchers as the most ideal mono-saturated fatty acid for bio-lubricant application. Biolubricants have edge over the conventional lubricants. For instance, bio-lubricants possess lower volatility, higher flash, less vapour emissions and oil mist, and constant viscosity that offer them better lubricity [19].

In other studies, the global transportation energy use is expected to increase by an average of $1.8 \%$ per year from 2005 to 2025 [70]. The International Energy Agency (IEA) report (2007), and Shahid and Jamal (2011) [66] have also indicated that the world will need $50 \%$ more energy in 2030 than compared to present use, of which $45 \%$ will be accounted for by China and India.

In this study, our focus is the statistical optimization of the production of bio-lubricants using Palm Kernel Oil (PKO) as feedstock.The choice of PKO was informed by its relative abundance. Besides, it has been reported that Nigeria ranks amongst the major world producers of PKO (USDA, 1998; [2]).

\section{Methodology}

The overall methodology for the synthesis of green lube oil is as depicted in Fig 1.

\subsection{Design of experiment using RSM}

Reaction time (mins), stirring speed ( $\mathrm{rpm})$ and catalyst concentration $(\% \mathrm{wt} / \mathrm{wt})$ as process variables were factored into the central composite experimental design Each of the independent variables was studied at three levels $(-1,0,+1)$, with 20 experimental runs. The levels were selected based on preliminary study, prior experience and information from literature. The variables optimized were Reaction time (60 - $120 \mathrm{mins})$, stirring speed $(800-1000 \mathrm{rpm})$ and Catalyst concentration $(0.75$ $\left.1.00{ }^{\circ} \mathrm{C}\right)$, respectively as contained in Table 1 .

Table 2 shows both the coded and uncoded values of factors and levels used in the experimental design. The statistical software Design Expert 10.0, (Stat-Ease Inc., Minneapolis, USA) was used to evaluate the analysis of variance $(\mathrm{P}<0.05)$, determine the significance level of each term in the model equation and to estimate the goodness of fit.

The percentage production yield was determined according to (1) while the percentage yield of bio-lubricant was determined using (2) 
Table 1. Experimental range and the levels of the variables

\begin{tabular}{ccccc}
\hline & Factors & High level $(+1)$ & Medium level (0) & Low level (-1) \\
\hline A & Reaction Time (mins) & 120 & 90 & 60 \\
B & Stirring Speed (rpm) & 800 & 900 & 1000 \\
C & Catalyst Conc. (\%wt/wt) & 0.75 & 0.875 & 1.00 \\
\hline
\end{tabular}

Table 2. Experimental design for synthesis of bio-lubricants

\begin{tabular}{|c|c|c|c|c|c|c|}
\hline \multirow{2}{*}{ Run } & \multicolumn{2}{|c|}{$\begin{array}{c}\text { Factor } 1(\mathrm{~A}): \\
\text { Reaction Time (mins) }\end{array}$} & \multicolumn{2}{|c|}{$\begin{array}{c}\text { Factor } 2(\mathrm{~B}): \\
\text { Stirring Speed (rpm) }\end{array}$} & \multicolumn{2}{|c|}{$\begin{array}{c}\text { Factor } 3(\mathrm{C}): \\
\text { Catalyst Concentration }(\% \mathrm{wt} / \mathrm{wt})\end{array}$} \\
\hline & Coded Value & Acual Value & Coded Value & Actual Value & Coded Value & Actual Value \\
\hline 1 & -1 & 60 & -1 & 800 & +1 & 1.000 \\
\hline 2 & 0 & 90 & 0 & 900 & +1 & 1.000 \\
\hline 3 & 0 & 90 & +1 & 1000 & 0 & 0.875 \\
\hline 4 & 0 & 90 & 0 & 900 & 0 & 0.875 \\
\hline 5 & -1 & 60 & 0 & 900 & 0 & 0.875 \\
\hline 6 & 0 & 90 & 0 & 900 & 0 & 0.875 \\
\hline 7 & 0 & 90 & 0 & 900 & 0 & 0.875 \\
\hline 8 & 0 & 90 & 0 & 900 & 0 & 0.875 \\
\hline 9 & 0 & 90 & -1 & 800 & 0 & 0.875 \\
\hline 10 & -1 & 60 & -1 & 800 & 0 & 0.750 \\
\hline 11 & -1 & 60 & +1 & 1000 & +1 & 1.000 \\
\hline 12 & +1 & 120 & +1 & 1000 & -1 & 0.750 \\
\hline 13 & 0 & 90 & 0 & 900 & -1 & 0.750 \\
\hline 14 & 0 & 90 & 0 & 900 & 0 & 0.875 \\
\hline 15 & +1 & 120 & 0 & 900 & 0 & 0.875 \\
\hline 16 & +1 & 120 & -1 & 800 & +1 & 1.000 \\
\hline 17 & 0 & 90 & 0 & 900 & 0 & 0.875 \\
\hline 18 & -1 & 60 & +1 & 1000 & -1 & 0.750 \\
\hline 19 & +1 & 120 & -1 & 800 & -1 & 0.750 \\
\hline 20 & +1 & 120 & +1 & 1000 & +1 & 1.000 \\
\hline
\end{tabular}

$$
\begin{aligned}
& \text { Production Yield }=\frac{\text { mass of unwashed biolubricant } \times 100}{\text { mass of methyl ester used }} . \\
& \% \text { yield of biolubricant }=\frac{\text { mass of dried biolubricant } \times 100}{\text { mass of methyl ester used }} .
\end{aligned}
$$

\subsection{Physio-chemical analysis of bio-lubricants}

The intermediate product (PKOME) and the synthesized bio-lubricant at optimum condition were analyzed for the following physio-chemical properties; viscosity, viscosity index, pour point, flash point, acid value and $\%$ free fatty acid (FFA) using standard methods. 


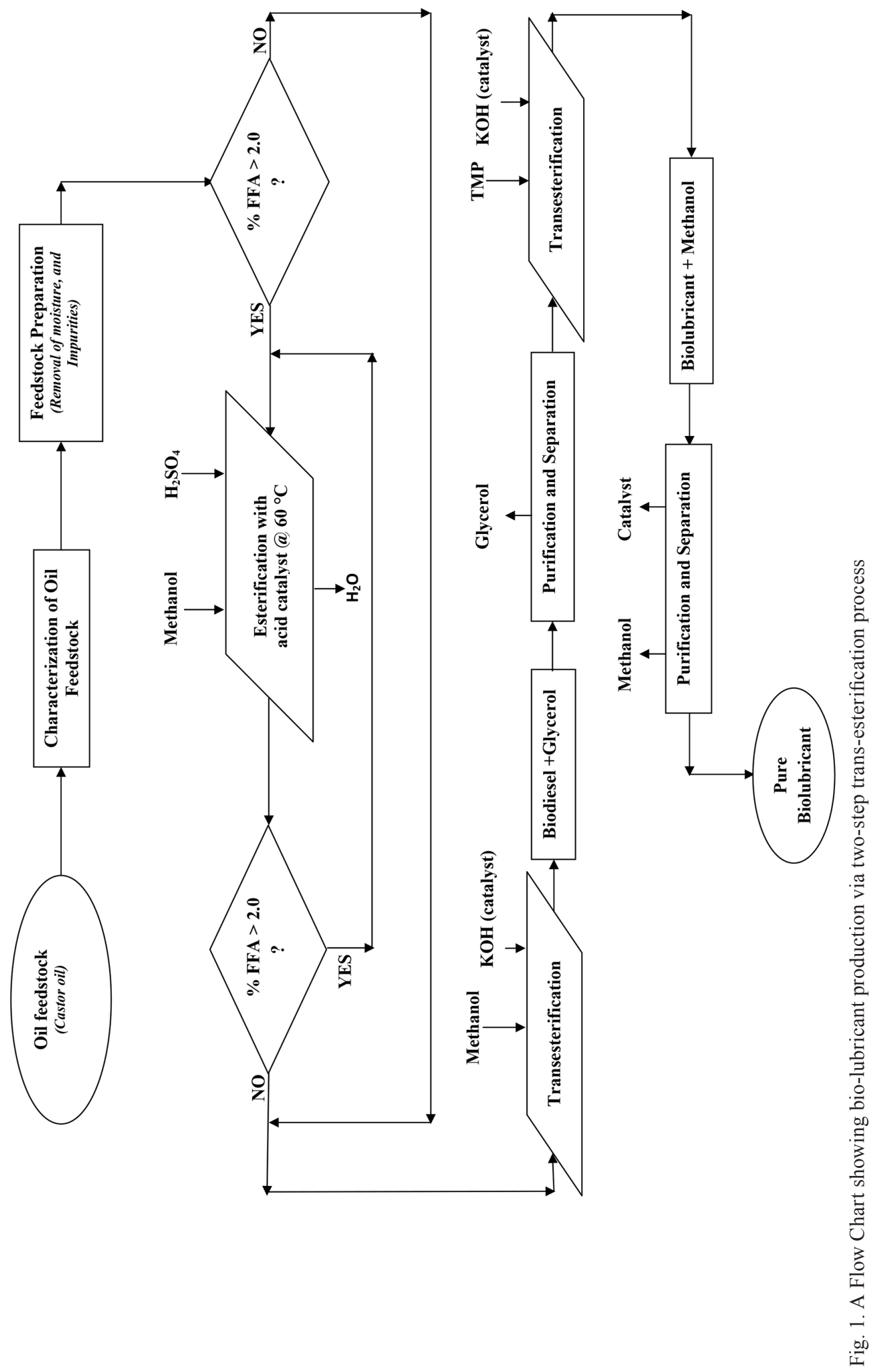




\subsection{Statistical modeling}

\section{Results and Discussion}

Table 3 depicts the actual and predicted yield of the bio-lubricant. The experimental data obtained from the trans-esterification reaction was analysed by the RSM regression using the polynomial equation shown in (3)

$$
Y=b_{o}+\sum_{i}^{k} b_{i} X_{i}+\sum_{i=1}^{k} b_{i i} X_{i}^{2}+\sum_{i>j}^{k} \quad \sum_{j}^{k} b_{i i} X_{i} X_{j}+e .
$$

Where $\mathrm{Y}$ is the response (yield of bio-lubricant), $X_{i}$ is the independence variables, $b_{o}$ is the intercept, $b_{i}$ is first order coefficient of the model, $b_{i i}$ is the quadratic coefficient of the $\mathrm{i}^{\text {th }}$ factor, $b_{i j}$ is the linear coefficient of the model for the interaction between the $\mathrm{i}^{\text {th }}$ and $\mathrm{j}^{\text {th }}$ varaiables, $k$ is the number of variables and $\mathrm{e}$ is the experimental error.

Experimental results were fitted using the polynomial (quadratic) equation (3) by multiple regression analysis to obtain the quadratic regression model for the trans-esterification of PKOME based on the coded values as shown in (4).

$$
\begin{aligned}
& Y=+97.53+4.78 A+0.48 B+0.52 C+0.21 A B+0.18 A C+0.32 B C- \\
& -6.20 A^{2}-0.036 B^{2}-0.026 C^{2}
\end{aligned}
$$

where $\mathrm{Y}$ is the bio-lubricant yield, $\mathrm{A}$ is the Reaction time, $\mathrm{B}$ is the stirring speed, and $\mathrm{C}$ is the catalyst concentration. The model equation in terms of actual factors is also presented in 5 .

Table 3. The actual and predicted yield of Bio lube oil yield

\begin{tabular}{cccc}
\hline Run Order & Actual value & Predicted value & Residual \\
\hline 1 & 86.25 & 86.24 & 0.011 \\
2 & 97.58 & 98.03 & -0.45 \\
3 & 97.52 & 97.98 & -0.46 \\
4 & 97.22 & 97.53 & -0.31 \\
5 & 86.31 & 86.55 & -0.24 \\
6 & 98.03 & 97.53 & 0.50 \\
7 & 97.61 & 97.53 & 0.077 \\
8 & 98.06 & 97.53 & 0.53 \\
9 & 96.81 & 97.02 & -0.21 \\
10 & 86.25 & 86.20 & 0.047 \\
11 & 87.57 & 87.40 & 0.17 \\
12 & 95.88 & 95.72 & 0.16 \\
13 & 96.77 & 96.99 & -0.22 \\
14 & 97.50 & 97.53 & -0.033 \\
15 & 95.69 & 96.12 & -0.43 \\
16 & 95.90 & 95.75 & 0.15 \\
17 & 98.11 & 97.53 & 0.58 \\
18 & 86.12 & 86.10 & 0.016 \\
19 & 94.98 & 94.98 & $1.114 \mathrm{E}-003$ \\
20 & 97.88 & 97.76 & 0.12 \\
\hline
\end{tabular}




$$
\begin{aligned}
& Y=+44.76+1.29 A-0.017 B-20.13 C+7.04 e-0.005 A B A C- \\
& -0.049 A C+0.025 B C-6.89 e-0.037 A^{2}-3.59 e-0.006 B^{2}-1.66 C^{2}
\end{aligned}
$$

\subsection{Fitness of model and analysis of variance (ANOVA)}

The statistical significance of the model was checked using the analysis of variance (ANOVA) and the coefficient of determination $\left(\mathrm{R}^{2}\right)$. The ANOVA was also used to determine the significance of each term in the model. The model was considered satisfactory when the ANOV A data showed a high level of significance. The statistical significance and fitness of the developed model as well as the significance of the individual and interacting terms were analysed using ANOVA and results obtained as shown in Table 4.

The model $\mathrm{F}$ - value of 266.96 and the $\mathrm{P}$ - value were found to be less than 0.0001 . This is an indication of the high significance of the model. The significance of each model terms was also checked using the $\mathrm{F}$ - value and $\mathrm{p}$ - value. Results indicated that the most significant term in the model was the reaction time (A) with an F-value of 1279.06, followed by the Catalyst concentration (B) with F - value of 15.00 and stirring speed with F-value of 12.77. Though, all the three variables are significant since all their p-values are less than 0.05 , but with varied level of significance (For a term to be significant, $\mathrm{p}$ - value must be less than 0.05) [1]. All interacting terms are insignificant since the P-values of AB, $\mathrm{AC}$ and $\mathrm{BC}$ are; $0.1881,0.2472,0.0605$ respectively which are greater than 0.05 . In this case $\mathrm{A}, \mathrm{B}, \mathrm{C}$, $\mathrm{A}^{2}$ are significant model terms.Therefore the terms; $\mathrm{AB}, \mathrm{AC}$, and $\mathrm{BC}$ can therefore be removed from the model for sensitivity analysis test. The lack of fit was also determined for the quadratic model. The lack of fit having the F-value of 1.68 and P - value of 0.2911 was not significant, an indication that the

\begin{tabular}{|c|c|c|c|c|c|c|}
\hline Source & $\begin{array}{l}\text { Sum of } \\
\text { squares }\end{array}$ & $\mathrm{df}$ & Mean square & F-value & P-value & Remark \\
\hline Model & 429.74 & 9 & 47.75 & 266.96 & $<0.0001$ & Significant \\
\hline A-Time & 228.77 & 1 & 228.77 & 1279.06 & $<0.0001$ & \\
\hline $\begin{array}{l}\text { B-Stirring } \\
\text { speed }\end{array}$ & 2.28 & 1 & 2.28 & 12.77 & 0.0051 & \\
\hline $\begin{array}{l}\text { C-Catalyst } \\
\text { concentration }\end{array}$ & 2.68 & 1 & 2.68 & 15.00 & 0.0031 & \\
\hline $\mathrm{AB}$ & 0.36 & 1 & 0.36 & 2.00 & 0.1881 & \\
\hline $\mathrm{AC}$ & 0.27 & 1 & 0.27 & 1.51 & 0.2472 & \\
\hline $\mathrm{BC}$ & 0.80 & 1 & 0.80 & 4.47 & 0.0605 & \\
\hline$A^{2}$ & 105.74 & 1 & 105.74 & 591.20 & $<0.0001$ & \\
\hline $\mathrm{B}^{2}$ & $3.546 \mathrm{E}-003$ & 1 & $3.546 \mathrm{E}-003$ & 0.020 & 0.8908 & \\
\hline $\mathrm{C}^{2}$ & $1.846 \mathrm{E}-003$ & 1 & $1.846 \mathrm{E}-003$ & 0.010 & 0.9211 & \\
\hline Residual & 1.79 & 10 & 0.18 & 1.68 & 0.2911 & \\
\hline Lack of Fit & 1.12 & 5 & 0.22 & 266.96 & $<0.0001$ & not significant \\
\hline Pure Error & 0.67 & 5 & 0.13 & & & \\
\hline Cor Total & 431.53 & 19 & & & & \\
\hline
\end{tabular}

Table 4. ANOVA result for the quadratic model

$\mathrm{R}^{2}=0-9959$, Adjusted $\mathrm{R}^{2}=0.9921$, Predicted $\mathrm{R}^{2}=0.9856$, Adequate Precision $=39.865, \mathrm{CV}=0.45 \%$. 

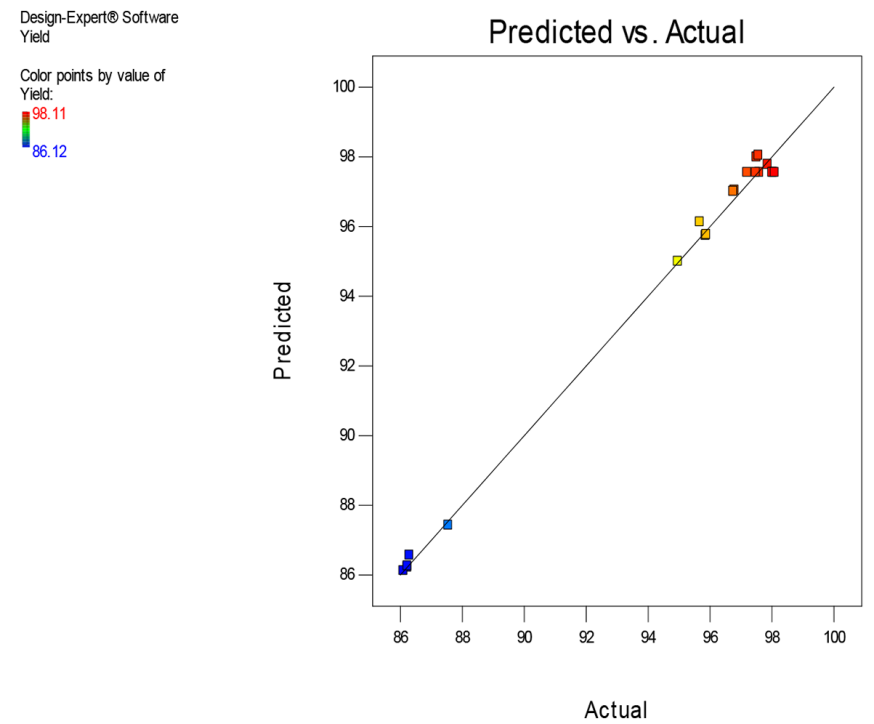

Fig. 2. Actual versus predicted bio-lubricant yield

model sufficiently describes the relationship between the trans-esterification variables and the biolubricant yield.

The coefficient of variation (CV) was also used to check the adequacy of the model. According to Daniel (1991), the CV should not be more than $10 \%$. The CV was $0.45 \%$, which further confirms the model adequacy. The $\mathrm{R}^{2}$ value was also used to test the suitability of the model. The $\mathrm{R}^{2}$ value of 0-9959 which is close to 1.0000 indicates an excellent agreement between experimental and predicted bio-lubricant yield [1]. The "Pred R-Squared" of 0.9856 is in reasonable agreement with the "Adj R-Squared" of 0.9921; i.e. the difference is less than 0.2. "Adeq Precision" measures the signal to noise ratio. A ratio greater than 4 is desirable. The ratio of 39.865 indicates an adequate signal. This model can be used to navigate the design space. A plot of the predicted bio-lubricant yield versus the actual bio-lubricant yield is shown in Fig. 2. The random scattering of data points around the diagonal line is further evident of the suitability of the developed model [1].

\subsection{Interactive Effect of process parameters on bio-lubricant yield}

The response surface plots shown in Fig. 3 describes the interactive effect of two variables on the bio-lubricant yield, while the other one variable is kept constant at their central point. The response surface plot of the bio-lubricant yield as a function of reaction time and stirring speed at a catalyst concentration of 0.95 wt. \% is shown in Fig. 3. It is observed that an increase in reaction time from 83 mins to about 100 mins at constant $926 \mathrm{rpm}$ increases the yield of bio-lubricant but beyond this limit the yield declines. Also it can be observed that the bio-lubricant yield also increases slightly as the stirring Speed incrreases at about 90 mins reaction time.

Fig. 4 shows the response surface plot of the bio-lubricant yield as a function of reaction time and catalyst concentration at constant stirring speed of $900 \mathrm{rpm}$. Similarly, it was observed that increasing the reaction time increases the bio-lubricant yield. However, beyond reaction time of 103.49 mins there is a decrease in the bio-lubricant yield. 


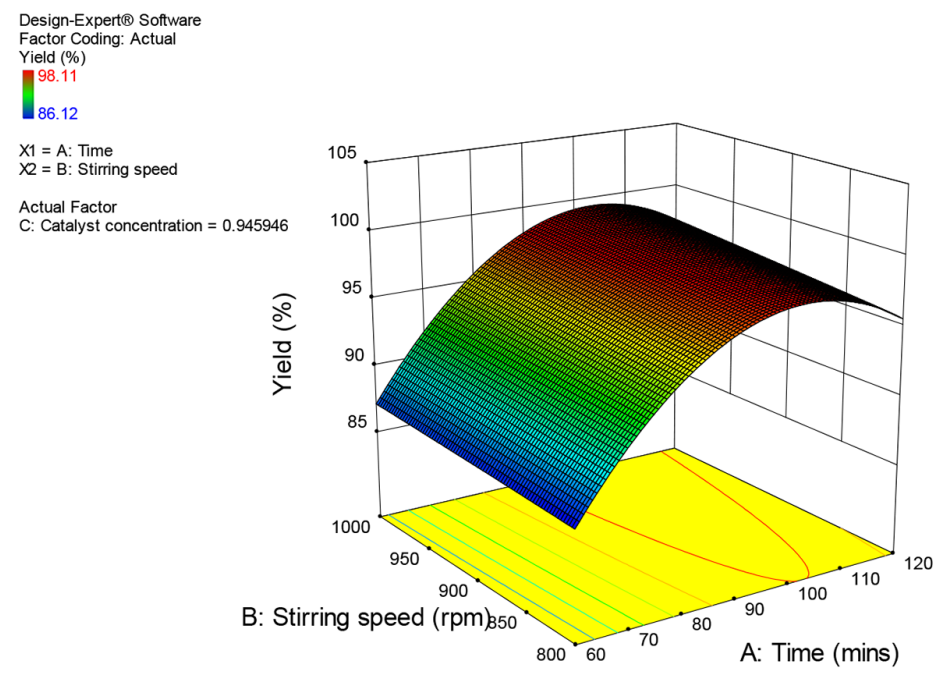

Fig. 3. Response surface plot of the bio-lubricant yield as a function of reaction time and stirring speed

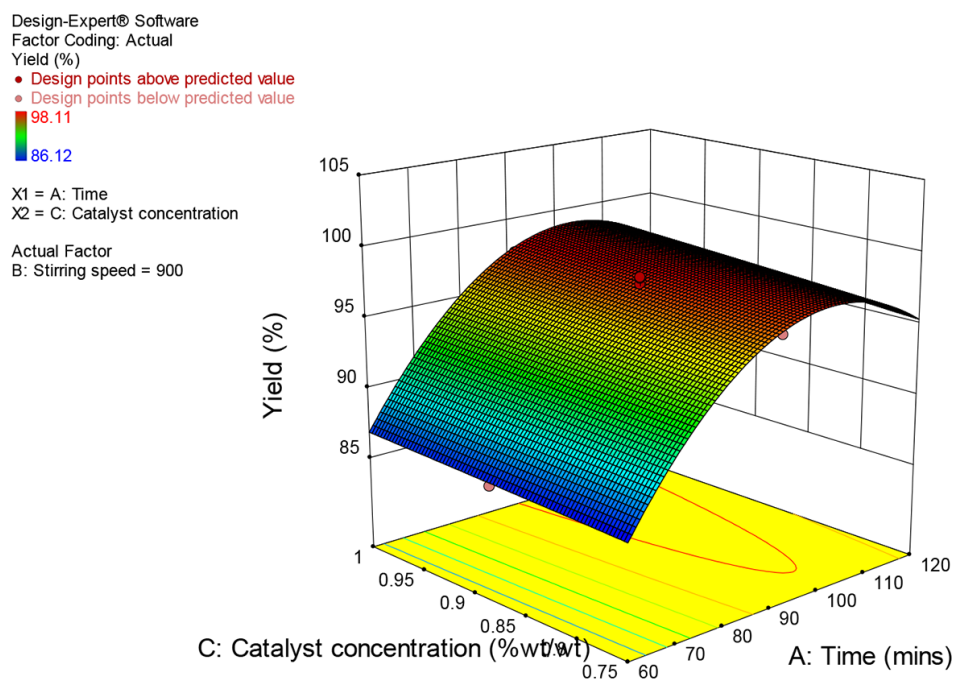

Fig. 4. Response surface plot of the bio-lubricant yield as a function of reaction time and catalyst concentration

Fig. 5 shows the response surface plot of the bio-lubricant yield as a function of stirring speed and catalyst concentration at constant reaction time of 90 mins. The figures shows that the effect of catalyst and stirring on yield of bio-lubricant is minimal compared to other factors or combination of factors studied. Increase in Stirring speed and catalyst concentration slightly increases the biolubricant yield.

\subsection{Optimization of Bio-Lubricant Yield and Validation of Model}

The optimum conditions for achieving maximum biodiesel yield was calculated using RSM numerical optimization. The solutions to the numerical optimization were; a reaction time of $99.9084 \mathrm{~min}$, stirring speed of $863.794 \mathrm{rpm}$ and catalyst concentration of $0.84522 \% \mathrm{wt} / \mathrm{wt}$. This was 


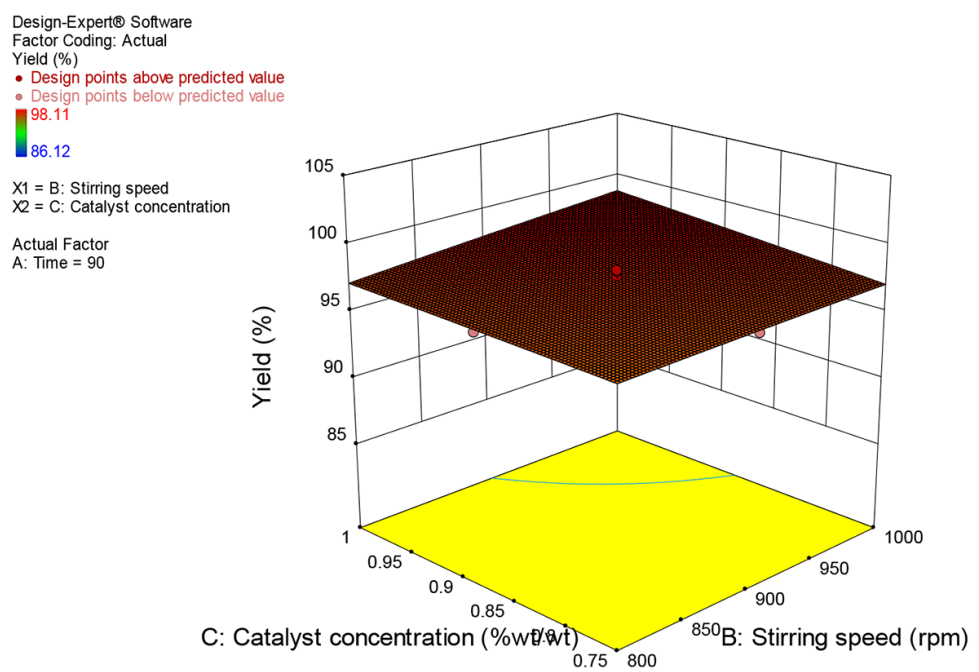

Fig. 5. Response surface plot of the bio-lubricant yield as a function stirring speed and catalyst concentration

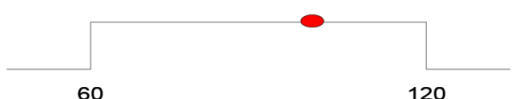

60

A: Time $=99.9084$

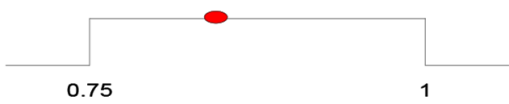

C: Catalyst concentration $=0.84522$

Desirability $=1.000$

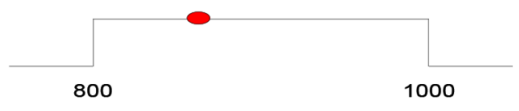

B:Stirring speed $=863.794$

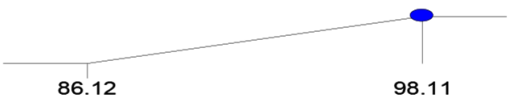

Yield $=98.1216$

Fig. 6. Various maximum point for experimental variables

the best solution out of 100 solutions, having the desirability of 1.00. Fig. 6 shows the various maximal point for each parameter that gave an optimum yield of 98.11.

For reproducibility and consistency of results, bio-lubricant synthesis was further carried out at the observed optimum conditions (99.9084 mins reaction time, $863.794 \mathrm{rpm}$ stirring speed, and $0.84522 \% \mathrm{wt} / \mathrm{wt}$ catalyst concentration) to obtain results as contained in Table 5. The discrepancy was 1.114 which further shows the adequacy of the model generated.

\subsection{Reduction in \% FFA of PKO}

Prior to trans-esterification reaction, the oil was esterified to reduce the $\%$ free fatty acid of the oil for elimination of possible side reaction. Table 6 shows the reduction in \% FFA with time.

\subsection{Characterization of the intermediate product (PKOME- a biodiesel)}

The intermediate product (PKOME) was characterized and the results are contained in Table 7. 
Table 5. Optimum conditions bio-lubricants yield

\begin{tabular}{cc}
\hline Parameters & Condition \\
\hline Reaction time (mins) & 99.9084 \\
Stirring Speed (rpm) & 863.794 \\
Catalyst Concentration (\%wt/wt) & 0.84522 \\
Optimal Yeild (\%) & 98.11 \\
Validated Optimal Yield (\%) & 96.996 \\
\hline
\end{tabular}

Table 6. Reduction in \% FFA with esterification reaction time

\begin{tabular}{cc}
\hline Reaction Time (mins) & \% Free fatty acid \\
\hline 0 & 3.95 \\
30 & 2.89 \\
60 & 0.68 \\
\hline
\end{tabular}

Table 7. Characterization of PKOME

\begin{tabular}{cccc}
\hline Parameter & PKOME & ASTM Standard & Petroleum diesel \\
\hline Density $\left(\mathrm{g} / \mathrm{cm}^{3}\right)$ & 0.8143 & $0.86-0.9$ & 0.84 \\
Acid Value & 0.82 & Max. 0.80 & 0.35 \\
\%Free fatty acid & 2.95 & Max. 0.40 & 0.175 \\
Kinematic Viscosity $\left(\mathrm{mm}^{2} / \mathrm{s}\right) @ 40^{\circ} \mathrm{C}$ & 5.22 & $1.9-6$ & 2.98 \\
Pour Point $\left({ }^{\circ} \mathrm{C}\right)$ & -4 & $-15-10$ & -12 \\
Flash point $\left({ }^{\circ} \mathrm{C}\right)$ & 141 & Min.130 & 74 \\
\hline
\end{tabular}

Source of Biodiesel ASTM and petroleum diesel standard are retrieved from Joseph C Obata [49].

\subsection{Physiochemical properties of bio lube oil synthesized}

The application of the synthesized bio-lubricant at optimum conditions was ascertained through conducted tests as depicted in Table 4.

\subsection{Physiochemical properties of PKO bio-lubricant}

The physicochemical properties of the bio-lubricant produced under optimal reaction conditions were analysed and compared with the petroleum lube oil shown in Table 8. It can be seen that the major fuel properties such as density, viscosity, viscosity index and flash point are not too far from the petroleum base except for the pour point. It was observed that the modification of the PKO through esterification reduces the flash point of PKO from $211{ }^{\circ} \mathrm{C}$ to a biodiesel flash point of $141{ }^{\circ} \mathrm{C}$ and subsequently increases again after reaction with TMP to $214{ }^{\circ} \mathrm{C}$ bio-lubricant flash point. The viscosity of PKO reduced from $35.55 \mathrm{~mm}^{2} / \mathrm{s}$ to $5.22 \mathrm{~mm}^{2} / \mathrm{s}$ biodiesel and improve to $29.23 \mathrm{~mm}^{2} / \mathrm{s}$ after modification with TMP. 
Table 8 . Physiochemical properties of synthesized bio lube oil

\begin{tabular}{ccc}
\hline Parameter & Synthesized lube oil & Petroleum lubricant \\
\hline Density $\left(\mathrm{g} / \mathrm{cm}^{3}\right)$ & 0.9834 & 0.848 \\
Kinematic Viscosity @ room temp. $\left(40^{\circ} \mathrm{C}\right)\left(\mathrm{mm}^{2 / \mathrm{s}}\right)$ & 29.23 & 46.476 \\
KinematicViscosity @ room temp. $\left(100^{\circ} \mathrm{C}\right)\left(\mathrm{mm}^{2 / \mathrm{s}}\right)$ & 3.67 & 6.940 \\
Pour Point $\left({ }^{\circ} \mathrm{C}\right)$ & -9 & -20 \\
Flash point $\left({ }^{\circ} \mathrm{C}\right)$ & 214 & $>220$ \\
\hline
\end{tabular}

Source: Petroleum lube oil standard was adopted from work of Michael Bong Alang et al [3].

\section{Conclusion}

This study has focussed on modelling and optimizing the process parameters on the production of bio-lubricant from palm kernel oil by reacting Palm kernel oil methyl ester (PKOME) and TMP (a polyol) together, using $\mathrm{KOH}$ catalyst. The optimization of the process parameters was done using response surface methodology (RSM) based on the central composite design (CCD). The parameters optimized in the production process are reaction time, stirring speed, and catalyst concentration. A second order quadratic model with $\mathrm{R}^{2}=0.9959$ was developed to predict the bio-lubricant yield. The predicted maximum biodiesel yield was $98.11 \%$ under the following conditions (reaction time of 99.9084 mins, stirring speed of $863.794 \mathrm{rpm}$, catalyst concentration 0.84522 . The reaction temperature and weight ratio were kept constant at $130{ }^{\circ} \mathrm{C}$ and 3.9:1 respectively. The experimental value obtained under these same conditions was $96.996 \%$. The quality of the bio-lubricant produced under these optimum conditions is in the range of the ASTM standard for bio-lubricant.

\section{References}

[1] Akhabue C.E. and Ogogo J.A. Modelling and optimization of transesterification of palm Kernel oil cat alysed by calcium oxide derived from hen Eggshell wastes, Ife Journal of Science, 2018, 20, no. 1 .

[2] Alamu O.J. Optimal Operating Conditions for the Production of Biodiesel from Palm Kernel Oil, unpublished Ph.D. thesis, Mechanical Engineering Department, Ladoke Akintola University of Technology, Ogbomoso, Nigeria, 2007.

[3] Alang M.B. et al. Synthesis and Characterisation of a Biolubricant from Cameroon Palm Kernel Seed Oil Using a Locally Produced Base Catalyst from Plantain Peelings. Green and Sustainable Chemistry, 2018, 8, 275-287.

[4] Amit Kumar Jain, Amit Suhane. Research Approach \& Prospects of Non Edible Vegetable Oil as a Potential Resource for Biolubricant - A Review", Advanced Engineering and Applied Sciences: An International Journal, 2012. Available at: http://www.urpjournals.com.

[5] Amit Suhane, Rehman A., Khaira H.K. Potential of Non Edible Vegetable Oils as an Alternative Lubricants in Automotive Applications, International Journal of Engineering Research and Applications (IJERA), 2012, 2, Issue 5, pp.1330-1335.

[6] AMSOIL, Syntheic Oil Canada n.d, Side-by-side comparison of synthetic vs conventional Mineral/Petrolium oil, AMSOIL Syntheic Oil Canada, 2009, viewed April 12. Available at: http://www. worldsbestoil.ca/long-engine-life.php 
[7] Anastasi U., Sortino O., Cosentino S.L., Patanè C. Seed yield and oil quality of perennial castor bean in a Mediterranean environment, Int. J. Plant Prod., 2015, 9, 99-116.

[8] Anjani K. Castor genetic resources: A primary gene pool for exploitation, Indust. Crops Prod., 2012, 35(1), 1-14.

[9] Azeez O.S. Production of biodiesel from palm kernel oil using FeO promotedsNaoH catalyst through transesterification, Journal of Applied Chemical Science International, 2016, 6(1), 40-44. ISSN: 2395-3705 (P), ISSN: 2395-3713 (O). International Knowledge Press.

[10] Banerji A.R., Chowdhury G., Misra G., Sudarsanam S.C., Varma G.S., Srivastava G.S. Jatropha seed oil for energy, Biomass, 1985, 8, 277-282.

[11] Basha S.A., Raja Gopal K., Jebaraj S. A review on biodiesel production, combustion, emissions and performance, Renew. Sustain. Energy Rev, 2009, 13, 1628-1634.

[12] Bilal S., Mohammed-Dabo I.A., Nuhu M., Kasim S.A., Almustapha I.H. and Yamusa Y.A. Production of biolubricant from Jatropha curcas seed oil, Journal of Chemical Engineering and Materials Science, 2013. ISSN 2141-6605.

[13] Bouflet A., Duteurte P., Airard P., et al. A challenge for the lubricant industries, Petrol Technol, 1991, 362, 65-79.

[14] Chilingarian G.V. and Vorabutr P. Drilling and Drilling Fluids, 1983.

[15] Da Silva J.A.C., Soares V.F., Fernandez-Lafuente R., Habert A.C., Freire D.M.G. J. Mol. Catal. B: Enzym., 2015, 122, p. 323-329.

[16] Demirbas A. Biofuels securing the planet's future energy needs. Energy Convers. Manage, 2009, 50, 2239-2249.

[17] Dosunmu A. and Joshua O. Development of environmentally friendly oil based mud using Palm-oil and groundnut-oil, 34th Annual SPE International Conference and Exhibition. Calabar: Society of Petroleum Engineers, 2010, pp. 1-9.

[18] Dunford N.T. Food and Industrial Bioproducts and Bioprocessing. John Wiley \& Sons, 2012.

[19] Dwight Smith \& Bob Frazier Archives, The Benefits of Bio-Based Lubricants, May, 2010. Available at: www.gearsolutions.com.

[20] Environmentally Preferable Purchasing Fact Sheet. Biolubricant. Department of Ecology, State of Washington, 2011, Publication No. 11-04-004.

[21] Freedman B., Pryde E.H. and Mounts T.L. Variables affecting the yield of fatty esters from transesterified vegetable oils, Journal of American Oil Chemists Society, 1984, 61(1), 1638.

[22] Gainer G.C., Luck R.M. Modified Castor Oil Lubricant for Refrigerator Systems Employing Halocarbon Refrigerants, 1979.

[23] Ghazi T.I., Gunam Resul M.F.M., Idris A. Production of an Improved Biobased Lubricant from Jatropha curcas as Renewable Source. Proceedings of Third International Symposium on Energy from Biomass and Waste, by CISA, Environmental Sanitary Engineering Centre (Venice) Italy, 2010.

[24] Givens W. Fuels and Lubricants Handbook: Technology, Properties, Performance, and Testing. G. Totten ed. et al. ASTM International, 2003, p. 373, ISBN 0-8031-2096-6.

[25] Haas M.J. Improving the economics of biodiesel production through the use of low value lipids as feedstocks: Vegetable oil soapstock. Fuel Process Technol., 2005, 86, 1087-1096.

[26] Hassan A.B., Abolarin M.S., Nasir A. and Ratchel U. Investigation on the Use of Palm Olein as Lubrication Oil. Leonardo Electronic Journal of Practices and Technologies, 2006, 5(8), 1-8. 
[27] Heinz P.B. Practical Lubrication for Industrial Facilities. Fairmont Press, 2009.

[28] Helene M. Biolubricants, technical and market survey, NOVAK SURVEY, 2007, 2.

[29] Hong D.-Y., Blackmore S. Plants of China: A Companion to the Flora of China. Cambridge University Press, 2015.

[30] Honory L. Biodegradable/biobased lubricants and greases. Machinary Lubrication, 2010.

[31] IENICA. Biolubricants: Market Data Sheet, IENICA, 2009, viewed April 12. Available at: http://www.ienica.net/marketdatasheets/biolubricantsmds.pdf

[32] Ioan S. On the future of biodegradable vegetable lubricants used for industrial tribo systems, Gal I Fascicie, 2002, VIII, 1221-4590.

[33] Jacques D., Briant J., Hipeaux J.-C. Lubricant Properties, Analysis and Testing', 1997, pp. 107-287. ISBN 2-7108-0746-7.

[34] Jumat S., Nadia S., Emad Y. Biolubricants: Raw materials, chemical modifications and environmental benefits, Eur. J. Lipid Sci. Technol., 2010, 112, 519-530.

[35] Kamalakar K., Mahesh G., Prasad R.B., Karuna M.S. J. Oleo Sci., 2015, 64(12), 1283 1295.

[36] Kazeem O., Taiwo O., Kazeem A., et al. Determination of some physical properties of castor (Ricirus communis) oil. Int. J. Sci. Eng. Technol., 2014, 3(12), 1503-1508.

[37] Lansdown A.R. Lubrication and lubricant selection: a practical guide. New York, ASME Press, 2004.

[38] Lashof D.A. and Ahuja D.R. Relative Contribution of Greenhouse Gases Emissions to Global Warming, Nature, 1990, 344, 529-531.

[39] Lou Honary A.T. Performance of biofuels and biolubricant, Biobased Industry Outlook Conference, National Ag-Based Lubricants Center University of Northern Iowa, 2008.

[40] Mang T., Lingg G., Mang I.T., Dresel W. Base oils, lubricants and lubrication, 2007, [chapter 4], 34-35.

[41] Martínez G., Sánchez N., Encinar J.M., González J.F. Biomass Bioenerg., 2014, 63, 22-32.

[42] Meher L.C., Sagar V.D. Nnik, S.N. Technical aspects of biodiesel production by transesterification - a review, Renewable and sustainable Energy Review, 2006, 10, 248-268.

[43] Miao X., Wu Q. Biodiesel production from hetrerotrophic microalgal oil. Bioresour. Technol., 2006, 97, 841-846.

[44] Mohammed Modu Aji, Shettima Abba Kyari and Gideon Zoaka. Comparative studies between bio lubricants from jatropha oil, neem oil and mineral lubricant (engen super 20w/50), Applied Research Journal, 2015, 1(4), pp. 252-257.

[45] Musa J.J. Evaluation of the Lubricating Properties of Palm Kernel Oil. Leonardo Electronic Journal of Practices and Technologies, 2009. ISSN 1583-1078.

[46] Musa U. et al. Evaluation of Oxidation Storage Stability of Biodiesel - Petrodiesel Blends. Nigerian Journal of Solar Energy, 2016, 27.

[47] Nagendramma P., Kaul S. Renew. Sust. Energ. Rev., 2012, 16, 764-774.

[48] Novel Methodology for the Synthesis of Acyloxy Castor Polyol Esters: Low Pour Point Lubricant Base Stocks.

[49] Obata J.C. Potentials of non-edible Abrus precatorius seed oil towards biodiesel production. African journal of biotechnology, full length research paper, 2014. 
[50] Onuh C.Y., Dosunmu A., Anawe P.A.L., Efeovbokhan V., Adebisi A. Transesterification of Non-Edible Vegetable Oil for Lubricant Applications in Water-Based Mud: A Review International Journal of Applied Engineering Research, 2017, 12(18), 7397-7401. ISSN 0973-4562.

[51] Pantzaris T.P and Mohammed J.A. Palm Kernel oil article. Palm Oil Research Institute of Malaysia (PORIM), 2000.

[52] Parsons G.M. Biodiesel and Engine Lubrication. Part 2, Califonia, Chevron Products Company, San Ramon, CA, 2007.

[53] Persson B. Historical Note, Sliding friction physical principles and application. Germany: Springer-Verlag, 2000.

[54] Placek D. Synthetics, Mineral Oils and Bio-based Lubricants, L. Rudnick ed., CRC Press, 2006, p. 519. ISBN 1-57444-723-8.

[55] Rahul G., Karmarkar A.S. Emerging trends and benefits of biolubricant. Chem Tech Foundation, 2013. Available at: http://www.chemtech-online.com/CP/rahul_july12.html

[56] Refaat A.A. Different techniques for the production of biodiesel from waste vegetable oil. Int. J. Environ. Sci. Technol., 2010, 7(1), 183-213.

[57] Reglitzky A., Kruntt Schneider H. The chances of exhaust emission reduction through conventional and alternative fuels. Deutsche Shell AG, 1992.

[58] Rudnick L.R. Automotives Gear Lubricants, J.l of Chemistry and Technology, 2006, 425-440.

[59] Sahoo D., Jena K.S., Rout P.K., Rao Y.R. Characteristics of Simarouba glauca seeds and fat of Orissa origin. J. Food Sci. Technol., 2002, 39(5), 552-555.

[60] Sahoo P.K., Das L.M., Babu M.K.G., Naik S.N. Biodiesel development from high acid value polanga seed oil and performance evaluation in CI engine. Fuel, 2007, 86, 448-454.

[61] Salimon J., Noor D.A.M., Nazrizawati A.T., Firdaus M.M., Noraishah A. Fatty acid composition and physicochemical properties of Malaysian castor bean Ricinus communis, L. seed oil. Sains Malays, 2010, 39(5), 761-764.

[62] Salimon J., Salih N. and Yousif E. Biolubricants: Raw materials, chemical modifications and environmental benefits, European Journal of Lipid Science and Technology, 2010, 112(5), 519-530.

[63] Scholz V., da Silva J.N. Biomass Bioenerg., 2008, 32, 95-100.

[64] Sevim Z., Brajendra E., Sharma K., Perez J.M. Oxidation and low temperature stability of vegetable oil-based lubricants, Industrial Crops and Products, 2006, 24, 292-299.

[65] Shah S., Sharma A., Gupta M.N. Extraction of oil from Jatropha curcas L. seed kernels by enzyme assisted three phase partitioning. Ind. Crops Prod., 2004, 20, 275-279.

[66] Shahid E.M., Jamal J. Production of biodiesel: a technical review. Renew. Sustain. Energy Rev., 2011, 15(9), 4732-4745.

[67] Sharma B.K., Adhvaryu A., Liu Z. and Erhan S.Z. Chemical modification of vegetable oils for lubricant applications. J. of the American Oil Chemists' Society, 2006, 83(2), 129-136.

[68] Singh C.P. and Chhibber V.K. Research Article Chemical Modification in Karanja, Oil for Biolubricant Industrial, 2013. 3(3), 117-122.

[69] Thomas A. Ullmann's Encyclopedia of Industrial Chemistry. Wiley-VCH Verlag GmbH \& Co. KGaA; 2000. Fats and fatty oils.

[70] Wagner H., Luther R., Mang T. Lubricant base fluids based on renewable raw materials. Their catalytic manufacture and modification. Appl. Catal. A: Gen., 2001, 221, 429-442. 
[71] Willing A. Lubricants based on renewable resource - an environmentally compatible alternative to mineral oil products, Chemosphere, 2001, 43, 89-98.

[72] Yang C.Y., Li Z.F.B., Long Y.F. Review and prospects of Jatropha biodiesel industry in China. Renew, Sustain. Energy Rev., 2012, 16, 2178-219.

[73] Zheng S., Kates, M., Dube M.A. and McLean D.D. Acid-catalyzed production of biodiesel from waste frying oil, Biomass \& Bioenergy, 2006, 30, 267-272. 